\title{
Facilitating online project collaboration \\ - new directions for learning design
}

\section{Inez Harker-Schuch}

Research assistant

Department of Plant and Environmental Science

University of Copenhagen

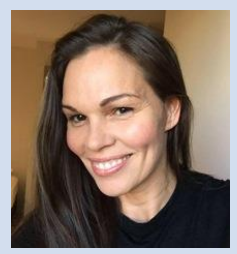

\section{Victoria Jae Chuang}

Research assistant

Department of Plant and Environmental Science University of Copenhagen

\section{Henrik Bregnhøj}

E-learning consultant

Center for Online and Blended Learning

University of Copenhagen

\section{Peter Furu}

Associate professor

Department of Public Health

University of Copenhagen
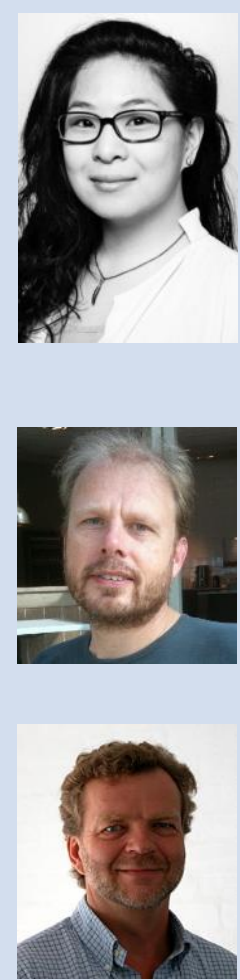


\section{Ingelise Andersen}

Associate professor

Department of Public Health

University of Copenhagen

\section{Christian Bugge}

\section{Henriksen}

\section{Associate professor}

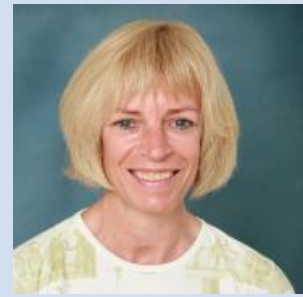

Department of Plant and Environmental Science University of Copenhagen

The authors have worked together for several years in an online and blended learning project at the University of Copenhagen 


\section{Abstract}

Although research suggests that project collaboration supports deep learning, facilitators frequently face participation and engagement challenges - particularly in $100 \%$ online courses and/or courses with students from diverse geographical/cultural backgrounds. The aim of this study was to investigate how students evaluate the online project collaboration component in two university courses over time and, thereby, define approaches that facilitate online project collaboration. We present our experiences with learning designs featuring online project collaboration by examining student evaluation of the team work component in the course 'Climate Change Impacts and Adaptation' (CCIAM) and reviewing specific process evaluation reports from the course 'Environmental Management in the Tropics'(EMiT). For the CCIAM we discern positive trends over the 2009-2012 period with 'collaborative dynamics', 'organisation/coordination', 'burden sharing' and 'practical knowledge' showing significant improvements following revision. We provide experience from revising the CCIAM course (responding to evaluations) - and reflect on the results that such revisions engender. Determining specific factors that contribute to improvements in student evaluations are not always clear but we offer suggestions for facilitating online project collaboration to circumnavigate the four above-mentioned major issues identified on the CCIAM course: these suggestions are peer assessment, mandatory participation, and grading (as a contribution to the overall final grade). For EMiT 'communication' showed the strongest significance and relevance - with organization/coordination, 'cultural issues' and 'learning outcomes' also indicating strong significance and relevance. We propose that learning designs for online project collaboration can be improved via teacher-facilitated interventions without undermining the socialisation pathways that students can find motivating and that promote online team building.

\section{Introduction}

\section{" Knowledge is intrinsically the common property of a group or nothing else at all" (Kuhn, 1970)}

In this article, we describe some of the challenges in facilitating team work in a university setting and, in particular, how this translates into an online working environment as a basis for designing a framework for successful collaborative project outcomes. We define 'online project collaboration' as a learning design featuring guidance-led instruction to engage and harness knowledge-building amongst peers - specifically, student peers - in the context of constructively and actively working together to solve problems, create and manage tasks, and to complete projects and activities in a team-based setting.

\section{The value of team-/group-work}

Team-/group-work is an important aspect of the Danish university teaching culture and is often implemented as part of the learning design, either in small projects as part of a course (which could be in the order of 20-50 hours per person) or at a couple of universities as projects that occupy half a semester to a whole year (375- 
1500 hours). The importance of team-/group-work supports both the creation of deep-learning as described in the theory of 'communities of practice' (Wenger, 1991) and 'peer learning' (Boud, Cohen, \& Sampson, 2014). Team/group work also reinforces vital civic connectedness; strengthening associative behaviours that are useful for adulthood, social cohesion, and civic responsibility (Hernández-Sellés, González-Sanmamed, \& Muñoz-Carril, 2014).

\section{Defining teamwork}

The specific team-based learning activities chosen for this paper deliberately emphasize teamwork rather than group-work. In this context a team is defined as 'a small number of people with complementary skills who are committed to a common purpose, performance goals, and approach for which they are mutually accountable' (Katzenbach \& Smith, 1993). Although students represent what is deemed a 'group', one of the characteristics of group work is that members are not necessarily accountable to each other whereas this is a vital component of teamwork (Johnson \& Johnson, 2003). In this sense, teamwork describes burden- and idea-sharing, communication, organisation and equal distribution of responsibility and ownership (particularly applying to the submission of the final project: report, assignment or project). Challenges associated with designing, facilitating and coordinating teamwork from a supervisory role are often generic and are easily conveyed into and often amplified in - an online learning environment (Hernández-Sellés et al., 2014)

\section{Team-work challenges in an online collaborative environment}

For online educators, designing collaborative online environments that encourage students to interact, argue constructively, exchange ideas and experience as well as produce high-quality deliverables are all well worth considering in order to encourage deep learning, as well as for socialisation/interaction which is vital for collaboration (Anderson \& Anderson, 2009; Janes, 2006; Ku, Hung, \& Akarasriworn, 2013; Stegmann, Wecker, Weinberger, \& Fischer, 2011). As important as these considerations are - and in spite of the many learning outcomes they promote - they are difficult activities to embed in online learning environments. Since most (if not all) communication and project development in these teams must take place in a virtual (and often asynchronous) environment, students often feel insecure and apprehensive - particularly if the student body is made up of individuals from diverse geographical/cultural backgrounds (Hernández-Sellés et al., 2014). Many different factors can hinder effective online project collaboration from the students' perspective aside from the unique communication environment found online. From a collaborations and group-dynamic perspective, these include differences in expectations or work ethics/standards (i.e. plagiarism), differences in educational and working background, different personalities, different disciplines, different experiences and different cultural attitudes and ambitions related to the work as 
well as psychological and behavioural constraints that prevent highly-effective interaction. From a logistics point of view, the hurdles include language proficiency, lack of familiarity with digital environments, suspicion of efficacy (some students find it difficult to imagine that online project collaboration is useful or even possible), internet access (that may need to handle a large data volume), unfamiliarity with digital tools/media (i.e. apps, software, browsers, passwords), and a simple lack of face-to-face communication that we rely on every day to interact with others (Curtis \& Lawson, 2001). It is, perhaps, this last issue that students find most difficult. A lack of in-person face-to-face communication something we are biologically primed to engage with - denies us certain information related to body language, environmental and social context, and other nuances that promote socialisation and inter-relatedness; particularly in an asynchronous activity and/or geographically-diverse team where both time and space are at odds with all participants. For example, those students who perform well in face-to-face environments might find that their conduct and execution are hindered by these new working environments - in contrast, others might find the online environment liberating insofar that they can 'hide' behind an online persona (Suler, 2004). Equally, too, the lack of formal or social requirements (courtesies, customs or chit-chat) may accelerate the interaction and aid in more effective communication than may be found in face-to-face activities. Educators and teachers face similar challenges (Salmon, 2000) and, to some degree or another, experience the same anxiety and reluctance to participate in online forums like learning management systems (LMS) that are focused on education (particularly online project collaboration) as their students do. In addition, and uniquely attached to their responsibility, they must accept roles of leadership and authority that are difficult to exercise in an online virtual environment. Altogether this makes for a complex and demanding state; it is necessary to ensure that, for the duration of a course or period of project development, the teamwork must be stabilised and managed to ensure all participants - students, teachers, facilitators, coordinators, and administrators - can connect, collaborate and participate in a meaningful learning experience.

\section{Aspects of learning design in online project collaboration}

Responding to the complexities of such an endeavour - and to develop a learning design that facilitates the interactions inherent in online project collaboration there are dynamics and structural considerations that are vital to include (Salmon, $\mathrm{Nie}$, \& Edirisingha, 2010). Aside from important logistics that all learning designs must incorporate in order to achieve planned learning outcomes (i.e. learning objectives, workload, deadline, guidance/instruction, resources, group size), there are many other vital aspects that are specific to online project collaboration that are necessary to incorporate, as well. These range from top-down controls (those driven and implemented by educators) - such as the previously mentioned 'logistics' - to 
bottom-up controls (those driven and implemented by the learner) such as burdensharing, organisation, time management to name a few. The importance of each aspect varies as a project develops, also - self-organisation, time management and equitable distribution of labour (or burden sharing) becomes more valuable than leadership as the project develops but is replaced by leadership and cohesion in the later stages of project collaboration. Developing a learning design for online project collaboration, therefore, must take these into account at the very early stages of curriculum planning to optimise the level of interaction, learning outcomes and project development.

\section{Objectives}

The overall objective of this study was to investigate how students evaluate the online project collaboration component in two university courses over time.

More specifically the objectives of the study were:

- To identify the issues that students assessed to be significant and meaningful.

- To explore how long-term adaptation efforts contribute to facilitating online project collaboration.

- To elucidate the dynamics between top-down (teacher-facilitated) and bottomup (student facilitated) online project collaboration

\section{Methodology}

\section{Study setting}

This paper presents results from two different courses: Climate Change, Impacts, Adaptation and Mitigation (CCIAM) and Environmental Management in the Tropics (EMiT). CCIAM has operated at the University of Copenhagen from 2009 to the present day. The CCIAM course is an interdisciplinary 15 ECTS online course based on the Fifth Assessment Report from the Intergovernmental Panel on Climate Change (IPCC). The course operates over a full semester (approximately 5 months) and, aside from a short 'in person' introduction to online learning (2-3 days that focuses on navigating the Learning Management System) and socialization period, the course runs online for the duration of this time. The diversity in the student group is very high - ranging from approximately 20-30 nationalities each year. There are strong Problem-based Learning (PBL) and collaborative learning activities in the course with the largest learning element consisting of 30 online discussions, two team assignments and a final individual assignment exam (Savery \& Duffy, 1994). Team assignments on 'National climate change adaption strategies' and 'National climate change mitigation strategies' are the principle online project collaboration activities and was one s of the most consistently revised elements in the course for the period 2009-2012. 
EMiT is a course that took place at the Technical University in Denmark, DTU from 1999 to 2014. From 2004, the course altered to include a distance-learning team. This resulted in two student groups: 1. Danish-based-students (DK students): international students physically at DTU, and 2. distance-learning students: Students following the course entirely online. Those students who took part from places outside of Denmark (distance-learning students) were admitted to take part in the course (and only that course) for free via a particular university agreement with universities mostly in Nicaragua, Costa Rica, Sri Lanka and Malaysia. The course provided 5 ECTS for the distance-learning students and 10 ECTS for the DK-based students (who, in addition, had an extra PBL task). The course had common weekly online lectures, small team or individual exercises, forum discussions and one major PBL-assignment on a self-selected subject. The PBL-assignment was implemented online in teams of 5-6 individuals, including both DK-students and distance-learning students.

\section{Data collection methods}

Evaluation discussions and reports supplied the data for this investigation as they represent the students' own responses to their experience of the online project collaboration in the two courses. In the CCIAM course, evaluation discussions take place in the middle of the course (midterm evaluation) and at the end of the course (final evaluation) whereby, in an online discussion forum, students are asked a series of questions relating to different components of the course. For EMiT, student teams write a process evaluation report at the end of the course where they assess and discuss the group interactions and work methodology - with a particular focus on the collaborative project interactions in a distance learning environment.

\section{Coding}

The coding methodology that was used to assess the evaluation discussions - and, subsequently, the evaluation reports - is a grounded theory approach based on Strauss and Corbin's model of 'open', 'axial', and 'selective' coding (Corbin \& Strauss, 1990). Data was extracted in similar ways in both courses with the significant difference being the allocation of issues (and hence number of codes) relevant to each course.

Students' evaluation comments were extracted from the discussions relating to the learning design (See Appendix 1) for the online project collaboration Team Assignment in the CCIAM course. Corresponding to the 'open' criteria for each issue to identify 'regular similarities and variations in a text'(LaRossa, 2005), the comments from individual students or teams were assigned a code relating to that particular issue. The open codes extracted from these comments were then allocated axial codes according to the onus of responsibility corresponding to Strauss and Corbin's (1990) definition of axial coding that look for 'causes, contexts, 
contingencies, consequences, covariances, and conditions' - resulting in 5 axial codes. For example, 'Burden sharing' is the responsibility of the student and, therefore, was assigned to the 'Collaboration' axial code (which is a wholly studentfacilitated realm) - 'Feedback/guide/tools is determined by the teacher and was, therefore, assigned to the 'Logistics' realm. Since the axial codes depend on a preexisting student-teacher dynamic, the axial codes aligned along a bar that ranged from wholly student-facilitated collaboration (bottom-up interventions), mostlystudent/partial teacher responsibility, shared responsibility, mostly-teacher/partial student responsibility, and wholly teacher-facilitated collaboration (top-down interventions) (Table 1).

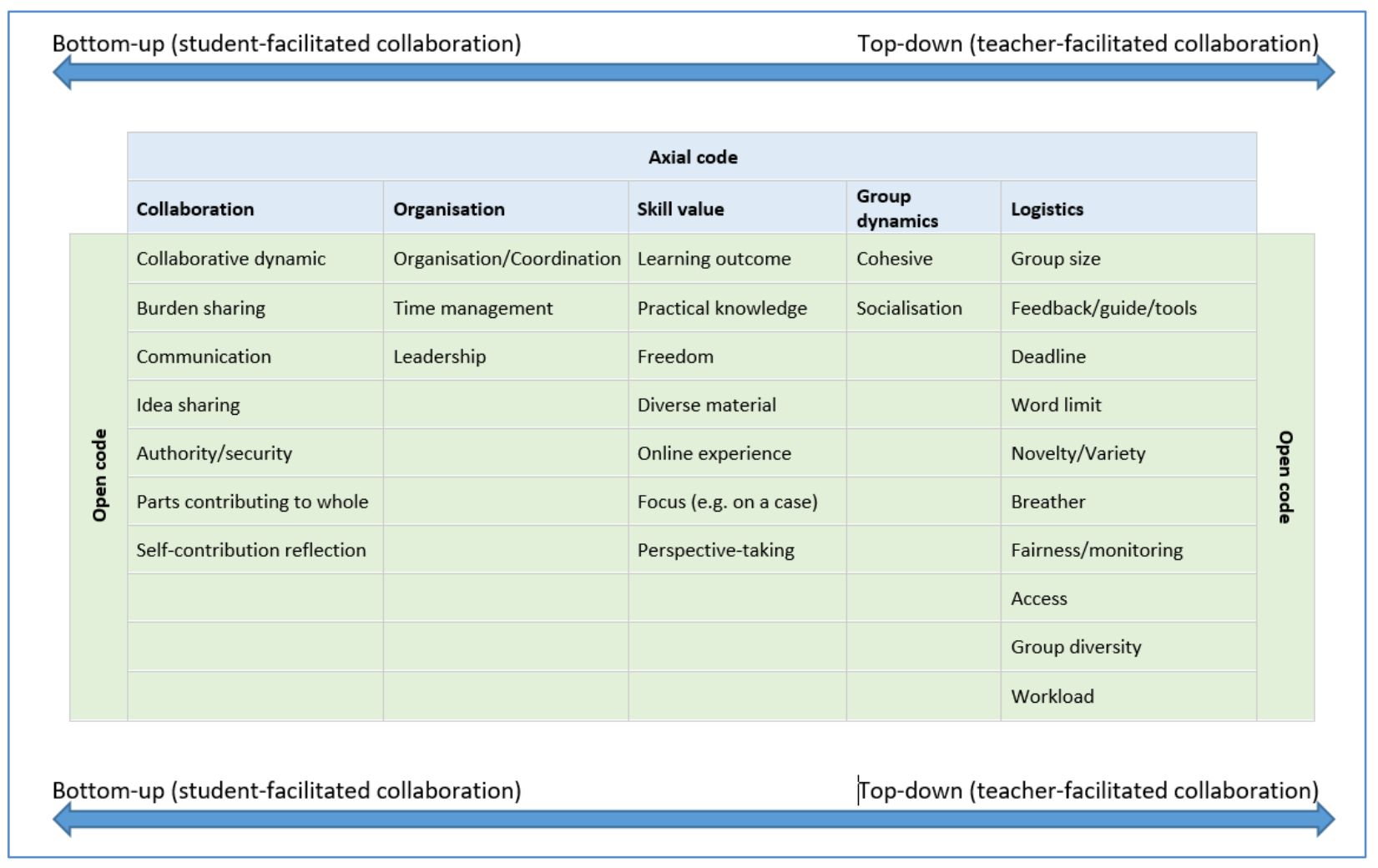

Table 1: Open and Axial Codes for CCIAM:

These open and axial codes were then applied to the 2009 and 2010 runs of the EMiT course for coding of the $\sim 10$-page process evaluation reports that are written by the mixed DK and distance student teams as an EMiT course requirement. These reports included reflections on the team work and students' learning.

Although the open codes applied for most of the process evaluation reports, two aspects were different between the CCIAM course and the EMiT course. Since team formation differs in the EMiT course compared to the CCIAM course, all students begin the course by completing a Belbin Team Role test to determine their individual typical 'team role behaviours'. This test was then used as the basis for team formation. Since the online project collaboration team assignments in the 
CCIAM course are formed within already established teams (with an elective sign-up to different case strategies) there is no specific team formation, so there is no coding for this in the CCIAM evaluation. In addition, the EMiT course operates across highly delineated cultural differences (with specific partner university agreements). Therefore, the open codes for 'group formation and 'cultural issues' have been added to the EMiT axial code. The axial codes remained the same for both courses (Table 2).

\begin{tabular}{|c|c|c|c|c|c|c|}
\hline \multicolumn{4}{|c|}{ Bottom-up (student-facilitated collaboration) } & \multicolumn{3}{|c|}{ Top-down (teacher-facilitated collaboration) } \\
\hline & \multicolumn{5}{|c|}{ Axial code } & \\
\hline & Collaboration & Organisation & Skill value & $\begin{array}{l}\text { Group } \\
\text { dynamics }\end{array}$ & Logistics & \\
\hline \multirow{11}{*}{ 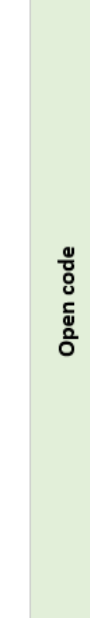 } & Collaborative dynamic & Organisation/Coordination & Learning outcome & Cohesive & Group size & \multirow{11}{*}{$\begin{array}{l}\text { 윰 } \\
\text { J } \\
\vdots \\
\vdots \\
\frac{0}{0}\end{array}$} \\
\hline & Burden sharing & Time management & Practical knowledge & Socialisation & Feedback/guide/tools & \\
\hline & Communication & Leadership & Freedom & & Deadline & \\
\hline & Idea sharing & & Diverse material & & Word limit & \\
\hline & Authority/security & & Online experience & & Novelty/Variety & \\
\hline & Parts contributing to whole & & Focus (e.g. on a case) & & Breather & \\
\hline & Self-contribution reflection & & Perspective-taking & & Fairness/monitoring & \\
\hline & Cultural issues & & & & Access & \\
\hline & & & & & Group diversity & \\
\hline & & & & & Workload & \\
\hline & & & & & Group formation & \\
\hline \multicolumn{4}{|c|}{ Bottom-up (student-facilitated collaboration) } & \multicolumn{3}{|c|}{ Top-down (teacher-facilitated collaboration) } \\
\hline
\end{tabular}

Table 2: Open and Axial codes for EMiT

Each comment was given a positive, negative or neutral value depending on the associated comment for the issue e.g. the comment 'Our team assignment went really fine - its (sic) good to work together in smaller groups' was coded as a 'group size +' and the comment 'It feels like quite a high workload for 4 people in the group' was coded as a 'group size -'. Comments that were suggestions for future revisions were valued as neutral. Overall, there were 29 open codes for CCIAM and 31 for EMiT that were sorted into the five valued axial codes. The tally of both of these issues from each code were then expressed as a percentage of those issues mentioned for both courses to determine the core variables. Since the CCIAM course had a longer data range (2009-2012) the open codes were then ranked by how often they were mentioned in the evaluation discussion to provide an overview of significant issues over time and within specific years. 


\section{Data analysis}

To determine the core variable (LaRossa, 2005) from the evaluations and to 'selectively' code the data as described by Strauss and Corbin (1990), the 29 open codes from the CCIAM that were only ranked as neutral or had $10 \%$ or less mentions as a sum from the evaluations in all the course years were considered negligible. The $10 \%$ threshold was selected as the majority of the 29 open codes fell above the $10 \%$ range, (18 of 29). From these open codes, specific open codes were considered negligible if they were above $10 \%$ but below $20 \%$ (for any one year - those with two years above $10 \%$ were kept for further sorting). Again, these thresholds were selected as the majority of the remaining codes fell between the $>10 \%$ and $<20 \%$ range - thereby highlighting any codes above the $20 \%$ threshold. To further focus the assessment, the remaining code mentions for each individual code were summed together (as a percentage) and divided by 4 (total number of years). Those that scored more than 20 were considered significant and were investigated more thoroughly. The significant open codes were then plotted individually from the assessment values ( + and -) to determine performance over time and investigate the performance of the course in relation to these issues.

\section{Comparison to course changes for CCIAM}

The significant open codes were then compared to revisions and changes (see Appendix 2)that were made to the learning design for the project collaboration element in the course (relative to the previous year's evaluation) to determine if the revisions and changes had improved the online project collaboration activities in the course and mitigated the issues that the students had mentioned in the previous course evaluations. In addition, to assess the open codes to determine if teachers, as facilitators of the entire online project collaboration, have significant influence over the student-facilitated collaboration open codes, we sorted the open codes into their respective axial codes and compared the significant changes based on facilitated collaboration responsibility. The evaluations of the students were also compared to the final anonymous evaluations of the course (an institutional requirement) to determine if other factors may have contributed to these results (e.g. any differences in average final grade/ overall course satisfaction, academic disciplines of student body). Finally, codes that were suggestions for future directions for the course (those valued as neutral) were compared to the revisions to see any effect on improvement.

\section{Results}

\section{CCIAM results}

Of the 29 open codes, sorted for significance above the $10 \%$ threshold, 6 open codes were considered negligible (Codes negligible $<10$ of total mentions (\%)) and, when applying the filter for those years when an issue was above $10 \%$ but below $20 \%, 10$ open codes were considered negligible (Table 3 ): 


\begin{tabular}{|c|c|c|c|c|}
\hline & Open code & $\begin{array}{c}\text { No. of } \\
\text { years } \\
\text { mentioned }\end{array}$ & $\begin{array}{l}\text { Mentions } \\
\text { coded as } \\
\text { neutral or } \\
<10 \%\end{array}$ & $\begin{array}{c}\text { Mentions } \\
>10 \% \\
\text { but } \\
<20 \%\end{array}$ \\
\hline \multirow{6}{*}{ 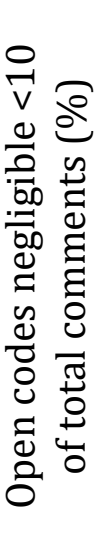 } & Access & 1 & $<10 \%$ & \\
\hline & Authority & 1 & $<10 \%$ & \\
\hline & Breather & 1 & $<10 \%$ & \\
\hline & Fairness & 1 & $<10 \%$ & \\
\hline & $\begin{array}{l}\text { Self-contribution } \\
\text { reflection }\end{array}$ & 2 & $<10 \%$ & \\
\hline & Leadership & 2 & $<10 \%$ & \\
\hline \multirow{10}{*}{ 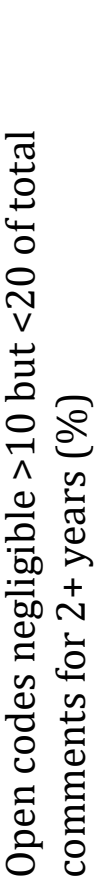 } & Deadline & 2 & $>10 \%$ & $<20 \%$ \\
\hline & Diverse material & 2 & $>10 \%$ & $<20 \%$ \\
\hline & Freedom & 2 & $>10 \%$ & $<20 \%$ \\
\hline & Feedback & 3 & $>10 \%$ & $<20 \%$ \\
\hline & Perspective-taking & 2 & $>10 \%$ & $<20 \%$ \\
\hline & Cohesive & 3 & $>10 \%$ & $<20 \%$ \\
\hline & Focus & 3 & $>10 \%$ & $<20 \%$ \\
\hline & Group diversity & 3 & $>10 \%$ & $<20 \%$ \\
\hline & Novelty & 3 & $>10 \%$ & $<20 \%$ \\
\hline & $\begin{array}{l}\text { Parts contributing to } \\
\text { a whole }\end{array}$ & 3 & $>10 \%$ & $<20 \%$ \\
\hline
\end{tabular}

Table 3: Thresholds for significance $<10 \%$ for all evaluations and $<20 \%$ for any one year. These Open codes are considered negligible.

The remaining 13 were further sorted to determine significant issues either over time or in particular years, resulting in 11 open codes being considered negligible and 4 open codes being considered significant (Table 4): 


\begin{tabular}{|c|c|c|c|c|}
\hline & Open Code & $\begin{array}{l}\% \text { of } \\
\text { total } \\
\text { mentions } \\
\text { across all } \\
\text { years }\end{array}$ & $\begin{array}{l}\text { No. of } \\
\text { years } \\
\text { menti } \\
\text { oned }\end{array}$ & $\begin{array}{l}\text { Value }(\% \\
\text { of total } \\
\text { mentions } \\
\text { /4) }\end{array}$ \\
\hline \multirow{9}{*}{ 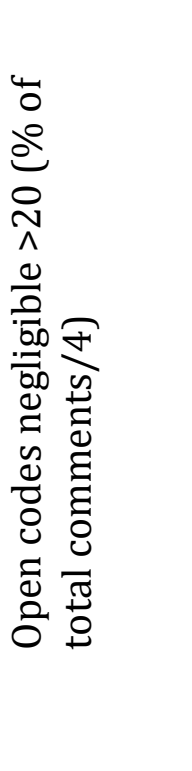 } & Idea sharing & 39 & 3 & 9.75 \\
\hline & Group size & 39 & 3 & 9.75 \\
\hline & Socialisation & 46 & 3 & 11.5 \\
\hline & Time management & 46 & 3 & 11.5 \\
\hline & Online experience & 47 & 2 & 11.75 \\
\hline & Workload & 54 & 2 & 13.5 \\
\hline & Learning outcome & 69 & 3 & 17.25 \\
\hline & Word limit & 69 & 3 & 17.25 \\
\hline & Communication & 73 & 3 & 18.25 \\
\hline \multirow{4}{*}{ 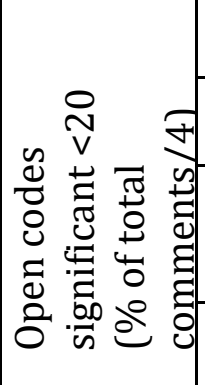 } & Practical knowledge & 81 & 2 & 20.25 \\
\hline & Burden sharing & 108 & 4 & 27 \\
\hline & $\begin{array}{l}\text { Organisation/coordinat } \\
\text { ion }\end{array}$ & 115 & 4 & 28.75 \\
\hline & Collaborative Dynamic & 165 & 4 & 41.25 \\
\hline
\end{tabular}

Table 4: Thresholds for significance $>20 \%$ and distributed over all years. These Open codes indicate significance. 


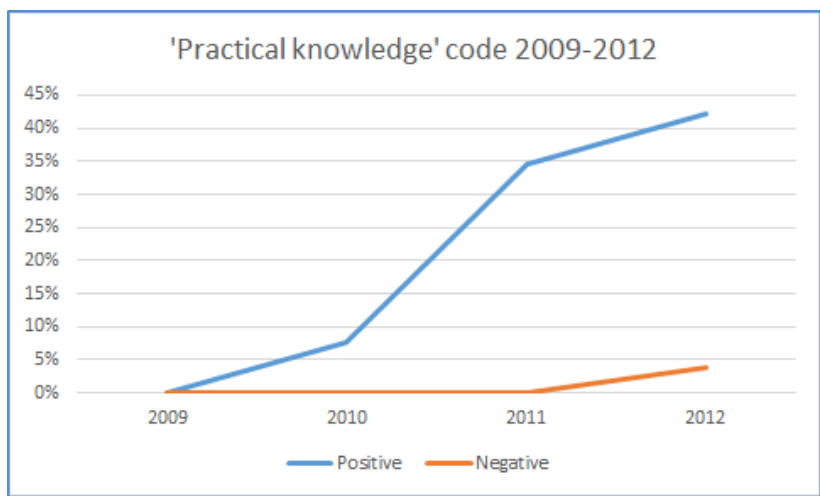

Performance over time

Figure 1: \% of positive over negative mentions for 'Practical knowledge' in CCIAM between 2009-2012

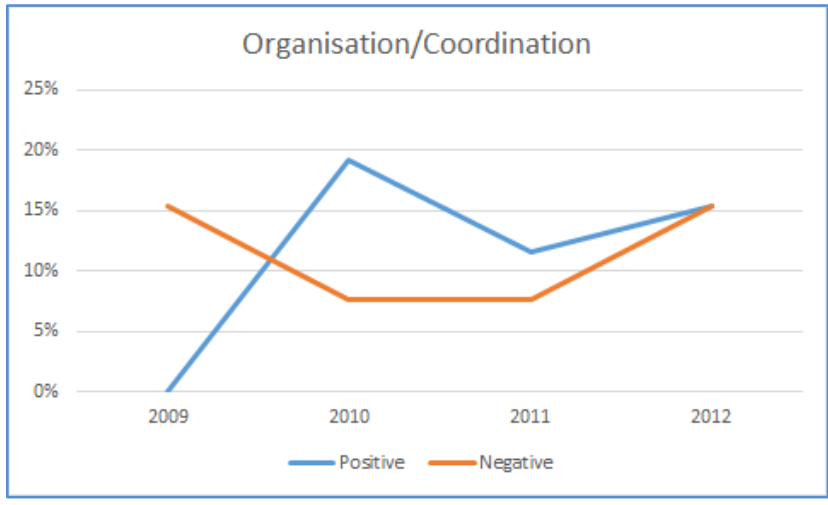

Figure 3: \% of positive over negative mentions for

'Organisation/Coordination" in CCIAM between 2009-2012

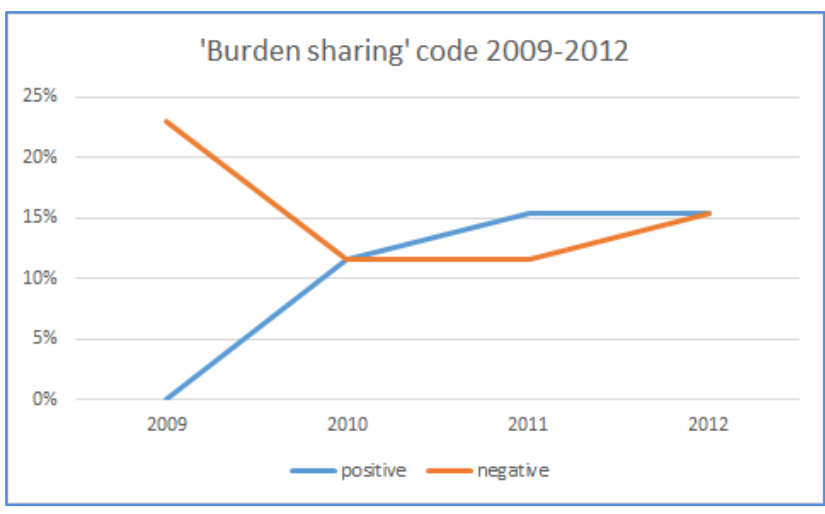

Figure 2: \% of positive over negative mentions for 'Burden sharing' in CCIAM between 20092012

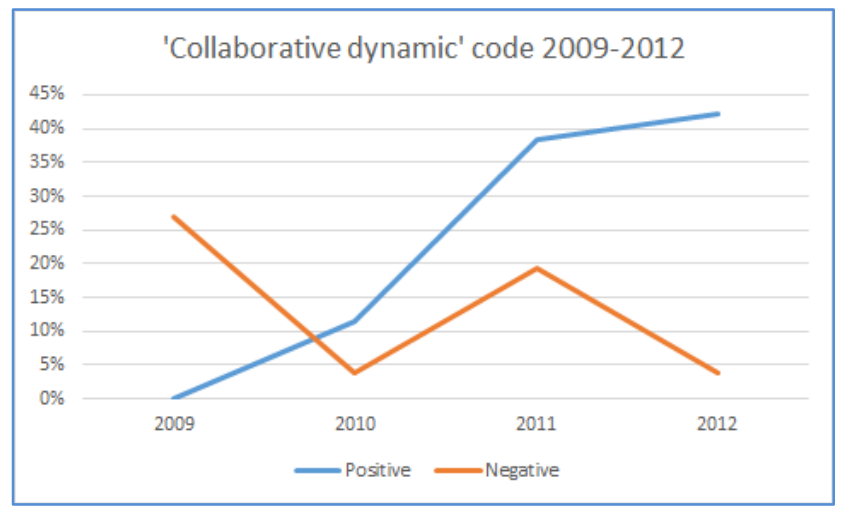

Figure 4: \% of positive over negative mentions for 'Collaborative dynamic' in CCIAM between 2009-2012

Student evaluation for the CCIAM course between 2009-2012 showed that positive comments increased in the open codes for 'Practical knowledge' (Fig 1), 'Burden sharing' (Fig 2) and 'Collaborative dynamic' (Fig. 4). 'Organisation/coordination' (Fig. 3), although following a drastic improvement between 2009 and 2010, decreased between 2010 and 2011 before showing an increase between 2011 and 2012. Negative comments associated with these same open codes indicate that 'Practical knowledge' had a small percentage between 2011 and 2012 only. Negative comments for both 'Collaborative dynamic' and 'Burden sharing', starting at high percentages in 2009 (approximately 25\%), dropped significantly in 2010 for 'Collaborative Dynamic', increased again in 2011by approximately $15 \%$ before decreasing to below $5 \%$. Negative comments for 'Burden sharing' remained stable between 2010 and 2011 and increased by less than 5\%. Negative comments for the open code for 'Organisation/coordination' decreased from just above 15\% to below $10 \%$ 
between 2009 and 2010, stabilised between 2010 and 2011 and then increased again to 2009 levels. Overall, results indicated an increase of positive comments in the evaluation rather than negative comments.

\section{Course evaluation and grade results}

In order to provide context for the above results and to clarify that student performance was not an influence on student evaluation, the following table shows overall student performance in the course from 2009-2012. Fewer students achieved high marks between the years 2010-2012, suggesting that the results of the evaluation were not influenced by overall student academic achievement.

\begin{tabular}{|c|c|c|c|c|c|c|c|c|c|c|c|c|}
\hline \multirow[t]{2}{*}{ Year } & \multirow{2}{*}{$\begin{array}{l}\text { No. of } \\
\text { respondents }\end{array}$} & \multirow{2}{*}{$\begin{array}{l}\text { No. of } \\
\text { respondents } \\
\text { of total } \\
\text { participating } \\
\text { students (\%) }\end{array}$} & \multirow{2}{*}{$\begin{array}{l}\text { Average } \\
\text { grade }\end{array}$} & \multirow{2}{*}{$\begin{array}{l}\text { Overall } \\
\text { satisfaction } \\
\text { level (\%) }\end{array}$} & \multirow{2}{*}{$\begin{array}{l}\text { Overall dis- } \\
\text { satisfaction } \\
\text { level }(\%)\end{array}$} & \multicolumn{7}{|c|}{ Grade distribution } \\
\hline & & & & & & 12 & 10 & 7 & 4 & 2 & 0 & -3 \\
\hline 2009 & 10 & 54 & 8.6 & 82 & 15 & 7 & 29 & 6 & 2 & 0 & 1 & 3 \\
\hline 2010 & 15 & 77 & 8.2 & 86 & 15 & 4 & 25 & 12 & 2 & 0 & 2 & 2 \\
\hline 2011 & 26 & 60 & 7.78 & 85 & 6 & 5 & 23 & 20 & 0 & 1 & 1 & 4 \\
\hline 2012 & 27 & 68 & 8.12 & 88 & 3 & 6 & 22 & 11 & 4 & 0 & 3 & 1 \\
\hline
\end{tabular}

Table 5: Course evaluation and grade results

\section{EMiT results}

The following open codes were mentioned most out of the total of 68 statements collected that were either positive or negative (include all open codes where more than one group mentioned the code):

\begin{tabular}{|l|l|l|l|l|l|l|}
\hline Open code & $\begin{array}{l}\text { Positi } \\
\text { ve }\end{array}$ & $\begin{array}{l}\text { Nega } \\
\text { tive }\end{array}$ & $\begin{array}{l}\text { To } \\
\text { tal }\end{array}$ & $\begin{array}{l}\% \text { of } \\
\text { menti } \\
\text { ons } \\
<10 \%\end{array}$ & $\begin{array}{l}\% \text { of } \\
\text { menti } \\
\text { ons } \\
>10 \%\end{array}$ & $\begin{array}{l}\% \text { of } \\
\text { menti } \\
\text { ons } \\
>20 \%\end{array}$ \\
\hline Group formation & $1 \%$ & $1 \%$ & $\begin{array}{l}3 \% \\
\%\end{array}$ & $<10 \%$ & $\mathrm{Na}$ & na \\
\hline Leadership & $0 \%$ & $3 \%$ & $\begin{array}{l}3 \\
\%\end{array}$ & $<10 \%$ & $\mathrm{Na}$ & na \\
\hline Online experience & $3 \%$ & $0 \%$ & $\begin{array}{l}3 \\
\%\end{array}$ & $<10 \%$ & $\mathrm{Na}$ & na \\
\hline Access & $0 \%$ & $4 \%$ & $\begin{array}{l}4 \\
\%\end{array}$ & $<10 \%$ & $\mathrm{Na}$ & na \\
\hline Idea sharing & $3 \%$ & $1 \%$ & $\begin{array}{l}4 \\
\%\end{array}$ & $<10 \%$ & $\mathrm{Na}$ & na \\
\hline
\end{tabular}




\begin{tabular}{|l|l|l|l|l|l|l|}
\hline Perspective taking & $4 \%$ & $0 \%$ & $\begin{array}{l}4 \\
\%\end{array}$ & $<10 \%$ & $\mathrm{Na}$ & na \\
\hline $\begin{array}{l}\text { Practical } \\
\text { knowledge }\end{array}$ & $5 \%$ & $0 \%$ & $\begin{array}{l}5 \\
\%\end{array}$ & $<10 \%$ & $\mathrm{Na}$ & na \\
\hline Time management & $3 \%$ & $4 \%$ & $\begin{array}{l}6 \\
\%\end{array}$ & $<10 \%$ & $\mathrm{Na}$ & na \\
\hline Learning outcome & $12 \%$ & $0 \%$ & $\begin{array}{l}12 \\
\%\end{array}$ & $>10 \%$ & $>10 \%$ & na \\
\hline Cultural Issues & $13 \%$ & $0 \%$ & $\begin{array}{l}13 \\
\%\end{array}$ & $>10 \%$ & $>10 \%$ & na \\
\hline $\begin{array}{l}\text { Organisation/Coor } \\
\text { dination }\end{array}$ & $12 \%$ & $6 \%$ & $\begin{array}{l}18 \\
\%\end{array}$ & $>10 \%$ & $>10 \%$ & na \\
\hline Communication & $8 \%$ & $14 \%$ & $\begin{array}{l}22 \\
\%\end{array}$ & $>10 \%$ & $>10 \%$ & $>20 \%$ \\
\hline
\end{tabular}

Table 6: Mention thresholds for significance $>10 \%$

The most important subject for the students has clearly been 'Communication' which got both negative and positive statements. Most of the positive statements were related to the use of skype/video-chat between the group members in Denmark and members in other countries (typical 1-3 in the same country/university, Nicaragua, Costa Rica, Malaysia among others). The groups found that the use of video-chat was very important or even made the whole difference in creating good communication among the team members, e.g. "Skype helped with communication and sharing of tasks and gave a feeling of Group connection" (group 1 2009). The most pronounced negative statement was related to the time difference. It was often 6-8 hours difference between students in Denmark and abroad and that seemed to limit the possibility for finding a good time slot for discussion when people at both locations are busy and several people should meet at each location: "it is difficult to meet at real time with 6 persons and work at the same time" (group 5 2010). It was also mentioned that, due to the ease for students in Denmark to meet in person and better understand the tasks (because they could meet teachers in person also) they sometimes tended to 'forget' to inform the distance students and just decided to do things.

The second most important subject was 'Organisation/Coordination', which was evaluated both positively and negatively. Many of the positive statements referred to well-organised meetings where the team had created a good structure with premade proposals for subjects, good minute-taking etc. and that they made good use of the group platforms in Moodle - particularly the discussion forum, e.g. "Group members were able to write (online) which subjects they would like to discuss at the next meeting (...) In this way the meetings became more structured and the 
conversation much more focused, and result/actions to eventual problems could be noted in the agenda so everyone could see what there was agreed on at all times." (Group 1 2009). The negative statements referred to different things such as delayed task conceptualisation: "The project was defined at a very late stage in the process, and therefore it has been difficult to plan the work for the project in specific tasks at the beginning." (Group 2 2009), or time-difference constraints: "the distance as well as time zone difference affected the group work a lot, little time for group meetings to talk over the topic" (Group 2 2009).

The third most important issue was 'cultural issues'. Although the statements were somewhat different, the comments were all positive. These differences related to an absence of cultural differences, "cultural differences has not (sic) really been experienced" Group 2 2009), group esteem comments: "all cultural difference has been faced successfully by the group members in order to do not harm the teamwork (sic)" (Group 4 2009), and the positive influence of cultural differences to the work/work environment "the multinational backgrounds leads makes us enjoy the time when we talk by Skype" (Group 1 2010)

The fourth most important issue was 'Learning outcome', which was only mentioned positively. Most teams responded that they have learnt to take responsibility because of the independence and self/-group-led assignment that many students are not accustomed to: "the best valuable thing which I have learned from all of you that is the team spirit and responsibility." (Group 2 2009), and "From smaller issues to bigger tanks, we learned to organize us in a decent manner to solve them and were thereby growing our team skills and abilities in group work" (Group 5 2010). Some teams point at having learnt to work online, "(Online/intercultural) communication were new to all group members, and it was very educational" (Group 3 2009). Many comments were given in the understanding: we had a lot of challenges like distance work and different educational and cultural backgrounds, and the challenges gave extra opportunity for learning.

One aspect worth mentioning - although not significant from the student evaluation due to the positive/negative value of the comments - is the code of Group formation. Most comments in the evaluation relate to the use of the Belbin Team Roles for making teams aside from one comment that argued: "we think the division of the Belbin Test is good, but it should not be the only factor taken into account. Availability, ambitions, interests and chemistry should also be taken into account in order to ensure a smoother running group work." (Group 1 2009). Other comments related specifically to the effectivity of the Belbin Team Role method. These comments ranged from high to low regard. From the high levels of success comments were: "it is really astonishing how this graph [Belbin composition] reflected actually the overall characteristics of the group and the way it worked" (Group 4 2009), while 
another team found the Belbin roles partially successful: "Overall, the Belbin-test shows some tendencies of the different group-members, but the roles were not really fixed" (Group 3 2009). One team commented: "the Belbin test was not representative compared to the work everyone did" (Group 5 2010). Mostly these statements were counted as 0 (relevant for the group work, but neither positive or negative) so they are not recorded in the numbers.

\section{Discussion}

Findings - CCIAM

Overall, there have been significant positive developments in the CCIAM course for the period 2009-2012 and these developments highlighted several findings in the assessment that provide valuable insight into developing learning designs to facilitate online project collaboration. The most significant trend in these assessments indicates that the overall coordination of project collaboration in this course has markedly improved for the period 2009-2012 and corresponds to the revisions of the learning design implemented from previous course evaluations. The second trend indicates a drastic improvement in two essential aspects of the project collaboration learning design - namely 'collaborative dynamic' and 'practical knowledge'. The assessment found, also, that three open codes for 'collaborative dynamic', 'organisation/coordination' and 'burden sharing' indicated significant persistent importance to the students in all course years (see Figures 1-4). Finally, a marked improvement between the 2009-2010 and the 2011-2012 years suggests there are other dynamics at play that contribute to online project collaboration and these will be examined further in the discussion.

For the 2009 CCIAM (signalling the start of this course at the University of Copenhagen), the evaluations of the team assignments were wholly negative with no positive comment in any aspect for the teamwork component of the course. The evaluations then showed improvement for each year afterward - corresponding to revisions of learning design for these courses advised by the preceding evaluations. Prior to the commencement of the 2010 course (following the 2009 evaluation), the online project collaboration component was made mandatory and an online peer assessment was implemented for all team members in each group (but not weighted to grade). In addition, mandatory authorship of the project, and increased course workload (from $20 \%$ to $40 \%$ ) were implemented to overcome a 'free-rider problem' (less committed students depending on the largesse or ambitions of other students to undertake their share of the workload). The course again improved from 2010 to 2011 with a reduction in dissatisfaction and a pronounced positive perception of 'collaborative dynamic' and 'practical knowledge' (see Figure 4 and 1, respectively). The significant change in this year was the appointment of a course coordinator who was solely responsible for the facilitation of the course (augmenting the existing role of coordinator in the preceding two years who, although administering the course 
and accompanying the students online throughout the course had other institutional responsibilities i.e. other online courses and department commitments). This result was supported in the overall course evaluation by a decrease from $15 \%$ to $6 \%$ from the year 2010 to 2011 (see Table 5). By 2012, results indicate that the previous years' improvement effect was further augmented with an increased positive evaluation for both 'collaborative dynamics' and 'practical knowledge'. This improvement reflects the effect of giving the project collaboration component a contribution to the final grade (12.5\% for each component to a total of $25 \%$ ).

Learning Design (Appendix 1)

\section{Motivations}

The results support many of the intended CCIAM Learning Design motivations (for course description see 'Study setting' under Methodology) - particularly those concerned with 'collaborative dynamic', 'Organisation/coordination', 'burden sharing' and 'practical knowledge'. These are specifically:

- Providing an environment for collaborative work that is engaging, motivating and beneficial to all participants (collaborative dynamic)

- Fostering an intellectual space that recognises the value of each participant's contribution within (and to) a collective whole (burden sharing)

- Ensure all participants contribute equally and enthusiastically to achieve the desired goals and milestones (organisation/coordination, burden sharing)

- Exploring, creating and establishing best-work practice for project collaboration that can be exercised in real-work work environments (practical knowledge)

- Overcome challenges to project collaboration in an online collaborative working space (collaborative dynamic)

\section{Learning Principle}

With regard to the learning principle or meta-pattern, the CCIAM course reflects the three structures and associated models that are employed to specifically facilitate online project collaboration - namely information exchange and knowledge construction (5-stage model) (Salmon, 2000), 'Constructivism and Problem-based learning' (PBL, (Savery \& Duffy, 1994), and online project collaboration (Tuckman model of team stages, (Joham \& Clarke, 2012) which describes the three phases of group development: bringing individual members into a cohesive, collaborative, problem-solving, and functional group towards achieving a goal, learning outcome or task). It is recognised that the Tuckman model overlies the meta-patterns of the 5-stage model (and, in some respects, the Constructivist/PBL model) for this course as these models occur within the Tuckman model structure. The Tuckman model supports the improved 'collaborative dynamic', 'organisation/coordination', and 'burden sharing' aspects of the CCIAM course - and these are further supported by the 5-stage model. The 'practical knowledge aspect is strongly supported by the 
constructivist/PBL model which is, in practice, designed to emulate real world scenarios and working environments.

\section{Resources}

Following the constructs of the learning principles mentioned above, the resources are designed to reflect the meta-patterns of project collaboration in the structure of the resources themselves. Online discussions form the primary foundation of information exchange and knowledge construction, while the online lectures, literature (including reports, data, models, maps) and questionnaires provide the foundation for problem-solving.

The assessment of the evaluations indicates that the improvement in the 'practical knowledge' code benefits from these resources and reinforces students' perceptions of their ability to participate in real-life problem-solving issues.

\section{Use cases}

For educators and teachers interested in implementing online project collaboration, our findings indicate that the following use cases may benefit from similar learning designs that have been implemented in the CCIAM course:

- Fostering an equitable distribution of tasks, work and effort (axial code: Burden-sharing)

- Transnational/cross-cultural online courses

- Collaborative online discussion courses (axial code: Collaborative dynamic)

- Collaborative online project courses (axial code: Collaborative dynamic)

- Conflict management and reduction (axial code: Organisation/coordination)

- Constructing an effective team-work environment (axial codes: Collaborative dynamic, organisation/coordination, burden sharing)

- Group-dynamic awareness-building (axial codes: Collaborative dynamic, Organisation/coordination)

- Creation of 'etiquette' and 'rules' in online project collaboration (axial codes: Collaborative dynamic)

- Structured frameworks for collaborative project development (axial codes: Collaborative dynamic, Organisation/coordination)

- Providing 'real-life' team work collaboration experiences (axial code: Practical knowledge)

\section{Significant open codes}

Similarly to the previous section, four major open codes were discerned: 'collaborative dynamic', 'practical knowledge', 'organisation/coordination', and 'burden sharing'. These findings are similar to previous research indicating comparable results (Avouris \& Yiannoutsou, 2012; Rae, Tayor and Roberts, 2006) 
For the online 'collaborative dynamic', we were unable to determine any specific revision that corresponded to the improvement in the course for this code. This may have occurred by eliminating the 'free-rider' problem but there are, undoubtedly, other influences to consider, as well. There are three additional factors that may have contributed to the changes from 2009 to 2011. The first is the appointment of a new coordinator to the course which would be a difficult factor to speculate upon, the second is that the course was not changed in terms of content or administration between the two years (2010-2011) and all the teachers would be familiar with the material and expectations, and the third was the hosting of the COP15 in Copenhagen 2009 which may have had mixed effects on the students ranging from disheartening to empowering.

With regard to the 'practical knowledge' code, there is again no attributable revision that could have abruptly improved the students' perception that the online project collaboration contributed to their practical knowledge or had real-world application. Discourses among the students may have shared this idea outside of the course platform that could have been triggered, in discussions with the students, by those administering and coordinating the course. Although 'practical knowledge' relates, by association, to 'knowledge construction', it is difficult to define the relationship beyond a natural learning progression. More investigation would be warranted to determine if this is the case and if this 'extended abstract' concept persists in future courses (i.e. the ability of an individual to theorise/generalise/hypothesise toward an untaught concept or idea from concepts and ideas they have been given instruction in (Shea et al., 2011)).

For the 'organisation/coordination' code the case is much clearer. As well as making the online project collaboration component mandatory, increasing the workload of the component and implementing a peer assessment for this in the 2010 course, the students were given a highly structured task that evolved over several weeks; a revision that eliminated the unstructured 'wiki' document (the initial format of the Team Assignment collaborative component when this course started in 2009 which was then replaced by an assignment-based document i.e. Adaptation or Mitigation Assignment) they had been asked to contribute to (with a reduced workload over a longer time frame) in 2009. This revision, it can be argued, gave the students far more clarity about their required tasks and their individual responsibility to complete that task.

For 'burden sharing' the case is also clear. In the 2009 version of the CCIAM course, the most significant problem was the 'free-rider problem' as was illustrated in the overwhelmingly negative evaluation of the course in that year. This is, for many educators implementing collaborative projects, one of the biggest problems that beset online learning. To overcome this, as previously mentioned, peer assessment 
was implemented and the assignments were made mandatory in 2010 (but without weight on the final course grade) which corresponds with an improvement in burden-sharing for the subsequent years (2010-2012). For the 2012 course, the team assignment was also included as a requirement for the final grade contributing to $25 \%$ of each individual's final grade in the course.

\section{Axial codes}

The significant open codes indicate, when attributed to their axial codes, that although teachers are the primary facilitators of the course, the issues that concern the students in the evaluation are, predominantly, student-facilitated open codes. Both 'Burden-sharing' and 'Collaborative dynamic' are wholly student-facilitated realms while 'Organisation/coordination' is only partially possible to facilitate with specific learning designs. For the 'Practical knowledge' open code, this is equally teacher and student facilitated - and is, for the most part, an extended abstract concept that can only be facilitated through experience and application of learned concepts. Intriguingly, as the evaluation indicates, the improvement of the course operates from a teacher-facilitated realm - that is, the teacher (or course coordinator), has implemented changes to the learning design, i.e. top-down controls - but secures (through these controls) bottom-up effects. This strongly supports the argument that teachers have considerable power to facilitate online project collaboration through learning design far beyond the reach of their own realms.

\section{Findings - EMiT}

The EMiT course differs in some significant ways from the CCIAM course. A large part of the participants were physically present in the Danish university and followed the course as part of their full-time study, while another part followed this one course) at a distance. The teams consisted of people from both groups. It created some imbalance and challenges in the teams, which affected the work.

A number of findings can be elucidated from the analyses above:

Communication is markedly more difficult when you can't meet the team members in person. It was found that video chat is helpful in creating a somehow similar situation to being together, thereby improving communication a great deal. This, presumably, has to do with the larger degree of connectedness that is felt with people you also know informally, which makes the working environment more fluid. Our experience from other group-work situations - where there is no distance work - is also that teams appreciate the work and working together much more, if they also allow themselves to meet informally for lunch or dinner or just take some hours to talk about other things. This is much easier to do when there is also a video link in the conversation. Against this stands the time difference, sometimes poor connectedness, combined with 4-6 people's busy non-synchronized schedules. The 
experience is that it hampers the possibilities of finding the necessary time to get a smooth collaboration. It seems that it is important to stress the use of video chat in this kind of team work that runs over 6-8 weeks.

With regard to organisation, it is often an eye-opener for students to participate in a PBL-like project, where the team has to - under supervision - identify the objectives, plan and carry out the project. Problem-oriented work in teams is highly prevalent in Northern Europe while it is virtually unknown in the Southern parts of Europe and most of the low-Income countries that our students come from. The outcome, in spite of a thorough introduction and supporting exercises (such as formulating project documents and planning parts of reports) is that the teams often diverge into two different types. The first are those who quickly find out how to structure the work and soon have clear objectives for the task; this may be due to the contribution of an experienced coordinator which enhances the learning experience for the other students and increases effective collaboration. The second type of team delays in identifying the project objective and, often they will not choose their subject and finalise the work until the last moment; with the result that the project is rushed and completed too hastily. Both teams, however, do end up appreciating the experience. They progress through the stages that they need to finish the work, and in the end, they feel they had a good learning experience. To effectively supervise all teams and to support deep learning, it is wise to encourage all teams to formulate and construct the objective early.

In terms of cultural issues, this study found that the cultural issues are not as hampering as could be expected (and have been observed in previous studies) when people in a team are from at least 4 countries in at least two continents (Zhu, 2012). One reason may be that university students are adapting to an international outlook. Perhaps, too, the influence of the Danish teamwork spirit somehow facilitates the development of a common 'educated culture' that learn - and share - values and working methods. Another reason may be that university students are better able to adapt to an international outlook due to the support of the teacher (who has emphasized some of the complexities related to cultural issues) in the first 1-2 weeks of the course. The course focus was on working in Tropical Regions and, for the European, predominantly Danish, students, that means working with (and for) people from those other cultures. So, it is part of the learning outcomes of the course to be able to work with people from other cultures and therefore it is continuously articulated as something positive to make it work - in spite of the challenges with language, culture, time, distance etc. In the end the students did not find that there were (difficult) cultural issues and that is seen as a positive outcome of the course.

Finally, the formation of teams using Belbin Team Roles is generally seen as a positive thing. The teams were formed by the teacher according to rules about 
difference in country of origin, gender and a good mix of Belbin team roles. It is necessary to note, however, that the teams in the distance-learning part of the group were usually formed from students from the same institution, to give them a chance to support each other. The feedback from the teams was mixed; in some teams, people assumed the roles predicted by the Belbin Team Role test and, in other teams, they assumed different roles than those the test revealed. Reasons for this may be that the team-role estimation is not so precise (especially people who are not used to formal team work may not know what their 'usual' behaviour is), or that other personal skills become more necessary in this learning situation where people have different levels of professionalism and experience and also that the bias between the team members in Denmark and those abroad makes it difficult for a certain type e.g. 'coordinator type' abroad to coordinate the team work. But whatever the result is, the students have become aware of the different roles it takes to do team work, both from the practical experience and from the more theoretical framework described by the Belbin Team Roles and, not least, from writing a process evaluation report about their experiences. From the course coordinator's viewpoint, the students come out with a solid understanding and good to high proficiency in working together in teams.

The experience of the learning outcome of the course participation is supported by both the project grade results as well as other course work and from the final evaluations. Marks are generally medium to high in the course and satisfaction levels are, typically, quite high.

\section{Conclusion}

Although the evaluation discussion in the 2009 CCIAM course reflects poorly on the structure of the learning design for the online project component at the time, we should not dismiss the useful course foundation established in 2009 which allowed for further development and adaptation. Such adaptation is vital in any processoriented task - particularly in order to maintain resilience, encourage progress and foster dynamism (Fath, Dean, \& Katzmair, 2015). The 2009 learning design was originally developed from a hybrid of several models: the 5-stage model, PBL, and constructivist learning. Since the online project collaboration takes place within an online course, the 5-stage model cannot be employed in its entirety- many of the stages are already functioning to support the project component (for example, the first stages of the 5-stage model have already been mastered by the students by the time they begin the online project collaboration components of the course i.e. the students are thoroughly familiar with access, corresponding and socialising, and have had many weeks experience in exchanging information. Therefore, there is little need to revisit these stages again). 
As any educator or online coordinator will know, facilitating online project collaboration is one of the most complex and difficult aspects of online education. The task requires many elements found in other aspects of online education - but contributes quite a few that are uniquely its own. The community of inquiry framework (Garrison, 2011) that harnesses the cognitive-social-teacher presence that supports such learning limits, by its very philosophy, the 'knowable' Cartesian model (that is, activity as a precursor to learning, rather than learning as a precursor to activity) that permits such environments to be created; online project collaboration is both a process and a specific structure (Goodfellow \& Lamy, 2009; Jonassen \& Rohrer-murphy, 1999). This paradox - the need for specific structural elements for the formulation of indistinct learning communities - can easily undermine endeavours to create such communities: the effort is always experimental. It must also be said that each online project collaboration - by the nature of the distinct collaborative teams - is unique in its own way (similarly to the Anna Karenina Principle interpreted from Tolstoy's 'Anna Karenina': “Happy families are all alike; every unhappy family is unhappy in its own way" (Diamond, 1997; Tolstoy, 1875). This uniqueness exacerbates strengths and flaws across groups and across years; making signals of success or failure quite difficult to determine. That said, there are many aspects of online project collaboration that do contribute greatly to knowledge formation - accelerating learning, promoting collaborations and providing real-world concepts and knowledge to those who participate.

It was clear, in the early development of the CCIAM course, that implementing a learning design featuring online project collaboration would be a very effective way to communicate many aspects of this highly interdisciplinary course - and provide many unique perspectives across a broad demographic of student participants. In theory, the construction of such a course seemed very straightforward: bring students together, task them with a goal and expectations - and set them free. The ideal group, however, depends on many other ideals: ideal students with similar learning ambitions, similar language skills, diverse academic skills/expertise, diverse cultural/social/gender perspectives - and so on. As every teacher with even a short period of teaching will tell you: such ideal groups do not exist. The task then, for the educator, is to level this 'learning field' and artificially create an environment that reflects this ideal.

By employing a learning design for online project collaboration (that should be embedded already across the whole online course framework) - and relying on sound pedagogic models to inform the learning principles (and, to a lesser extent, the resources) - it is possible to create a component that is highly receptive to revision and adaptation that will allow any teacher (or coordinator) to adjust and improve the learning design for online project collaboration component over time. 
This malleability is a vital quality for such collaborations and provides a flexible online component without loss of stability and fidelity.

Two aspects are particularly remarkable in the CCIAM evaluation discussion - the first is language and the second is experience with online project collaboration. Although many of the teachers struggle with the broad range of language skills in the course, none of the students have mentioned this in the evaluation - which is intriguing for a component that relies very heavily on communication (in an extremely diverse student group) in order to be effectively discharged. The other intriguing feature is how well non-Danish students adopt the teamwork spirit often without having any previous experience with this teaching method. Finally, from a course coordinators viewpoint, the most important aspect for facilitating online collaboration is the implementation - at the very outset of project commencement - of a collaborative dynamic within each team; that is, to ensure that all students articulate their expectations, their strengths and their weaknesses to their team and then, as a consequence, negotiate how they will approach their project. As an extension of this, each team can then begin to structure the work and assign tasks/roles that facilitate the collaboration amongst themselves. Facilitating this collaborative dynamic is, without doubt, the responsibility of the teacher/educator (most particularly for early tertiary students i.e. bachelor-level studies - and those not accustomed to project team work) and requires considerable planning and consideration. The benefits of embedding this element into the learning design are enormous - the most immediate and apparent being the reduced administrative burden of students who are insecure or unhappy with dysfunctional teams.

In the EMIT course the challenges and negative experiences for some students and groups were mainly with the communication and organization. But there is not one single approach that fits all, since synchronous communication like skype calls are essential in some groups and other groups function better with asynchronous communication, because of time differences and busy schedules. So, the conclusion is that groups should be supported in testing the communication channels early, as well as agreeing on a subject and work-plan early. The intentional-mixed student groups are often successful because students quickly recognise the value of working closely with people from other cultures and becoming aware of the various team roles in group-working environments. Some students do, of course, find it cumbersome to overcome the difficulties but, overall, they are able to appreciate the learning experience that is gained in such a learning environment.

Clearly, facilitating online project collaboration is not easy - but teachers have a great deal of control in how the students respond to the task, perceive it and, in addition, recognise the larger, real-world benefit. Facilitating these perceptions 
contribute greatly to engagement and motivation - and may well provide longerterm benefits in real-world situations for students who have enjoyed the task and recognised the larger 'big picture' relationship. There is no doubt that more precise frameworks, and models, would benefit those intending to implement learning designs for online project collaboration - but it is reassuring to think that experimenting with this component can be undertaken in a controlled and stable environment building on existing learning designs. We recommend, therefore, that those intending to implement online project collaboration activities consider employing frameworks and learning designs that allow easy adaptation and evolution; all activities should have the potential to be upgraded/updated over time. These frameworks and learning designs often depart from pre-existing models and methodologies that lend themselves easily to adaptation along the whole range of participation; from teacher-facilitated to student facilitated online project collaboration. 


\section{Referencer}

Anderson, T., \& Anderson, T. (2009). The Theory and Practice of Online Learning (5th ed.). AU Press, Athabasca University.

Avouris, N., \& Yiannoutsou, N. (2012). A review of mobile location-based games for learning across physical and virtual spaces. Journal of Universal Computer Science, 18(15), 2120-2142. http://doi.org/10.1016/j.compedu.2011.04.006

Boud, D., Cohen, R., \& Sampson, J. (2014). Peer Learning in Higher Education: Learning from and with Each Other. Psychology Press.

Corbin, J., \& Strauss, A. (1990). Grounded Theory Research : Procedures , Canons and Evaluative. Zeitschrift Für Soziologie, 19(6), 418-427.

Curtis, D. D., \& Lawson, M. J. (2001). Exploring collaborative online learning. JALN, 5(1).

Diamond, J. (1997). Guns, Germs, and Steel: The Fates of Human Societies. W.W. Norton \& Company.

Fath, B. D., Dean, C. A., \& Katzmair, H. (2015). Navigating the adaptive cycle: an approach to managing the resilience of social systems. Ecology and Society, 20(2). http://doi.org/10.5751/ES-07467-200224

Garrison, D. R. (2011). E-Learning in the 21st Century: A Framework for Research and Practice. Taylor and Francis.

Goodfellow, R., \& Lamy, M.-N. (2009). Learning Cultures in Online Education. A\&C Black.

Hernández-Sellés, N., González-Sanmamed, M., \& Muñoz-Carril, P. C. (2014). Planning Collaborative Learning in Virtual Environments. Comunicar, 21(42), 25-33. http://doi.org/10.3916/C42-2014-02

Janes, G. (2006). Addressing the learning needs of multidisciplinary students at a distance using a virtual learning environment (VLE): A novice teacher reflects. Nurse Educ Pract, 6(2), 87-97. http://doi.org/10.1016/j.nepr.2005.09.003

Joham, C., \& Clarke, M. (2012). Teaching critical management skills: the role of problembased learning. Teaching in Higher Education, 17(1), 75-88. http://doi.org/10.1080/13562517.2011.590975

John Rae Carole Roberts, G. T. (2004). Collaborative Learning: A connected community for learning and knowledge management. Interactive Technology and Smart Education, $3(3), 225-233$.

Johnson, D. W., \& Johnson, R. T. (2003). Assessing Students in Groups: Promoting Group Responsibility and Individual Accountability. Corwin Press.

Jonassen, D. H., \& Rohrer-murphy, L. (1999). Activity theory as a framework for designing constructivist learning environments. Educational Technology Research and Development, 47(1), 61-79. Retrieved from http://link.springer.com/article/10.1007/BF02299477

Katzenbach, J., \& Smith, D. (1993). The Wisdom of Teams: Creating the High-Performance Organization. Harvard Business Press. 
Ku, H.-Y., Hung, W. T., \& Akarasriworn, C. (2013). Collaboration factors, teamwork satisfaction, and student attitudes toward online collaborative learning. Computers in Human Behavior, 29(3), 922-929. http://doi.org/10.1016/j.chb.2012.12.019

Kuhn, T. S. (1970). The Structure of Scientific Revolutions (Vol. II). The University of Chicago Press. http://doi.org/10.1119/1.1969660

LaRossa, R. (2005). Grounded Theory Methods and Qualitative Family Research. Journal of Marrige and Family, 67(November), 837-857. http://doi.org/10.1111/j.17413737.2005.00179.x

Salmon, G. (2000). E-moderating: The key to teaching and learning online (2nd ed.). London: Taylor \& Francis Books Ltd.

Salmon, G., Nie, M., \& Edirisingha, P. (2010). Developing a five-stage model of learning in Second Life. Educational Research, 52(2), 169-182. http://doi.org/10.1080/00131881.2010.482744

Savery, J. R., \& Duffy, T. M. (1994). Problem Based Learning: An instructional model and its constructivist framework. Centre for research on learning and technology.

Shea, P., Gozza-Cohen, M., Uzuner, S., Mehta, R., Valentinova Valtcheva, A., Hayes, S., ... Remi, F. (2011). The Community of Inquiry framework meets the SOLO taxonomy: a processproduct model of online learning. Educational Media International, 48(2), 101-113. http://doi.org/10.1080/09523987.2011.576514

Stegmann, K., Wecker, C., Weinberger, A., \& Fischer, F. (2011). Collaborative argumentation and cognitive elaboration in a computer-supported collaborative learning environment. Instructional Science, 40(2), 297-323. http://doi.org/10.1007/s11251011-9174-5

Suler, J. (2004). The online disinhibition effect. CyberPsychology \& Behavior, 7(3), 321-326. http://doi.org/10.1089/1094931041291295

Tolstoy, L. (1875). Anna Karenina.

Wenger, E. (1991). Situated Learning: Legitimate Peripheral Participation. Cambridge, England: Cambridge University Press.

Zhu, C. (2012). Student Satisfaction, Performance, and Knowledge Construction in Online. Journal of Educational Technology Society, 15, 127-136. Retrieved from http://www.ifets.info/journals/15_1/12.pdf 


\section{Appendix 1}

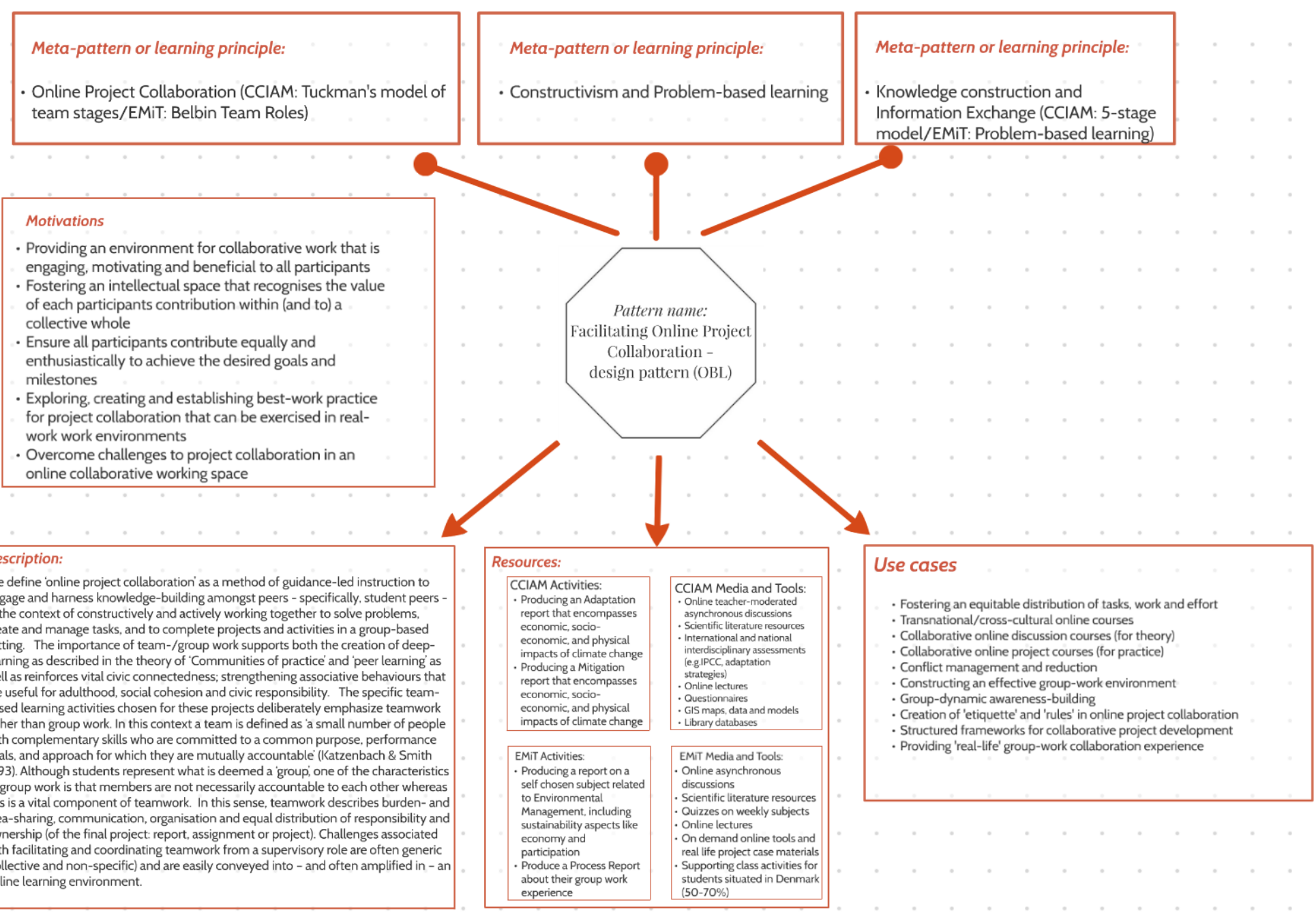




\section{Appendix 2}

\begin{tabular}{|c|c|c|c|c|c|c|c|}
\hline Year & 2009 & 2010 & 2010 & 2011 & 2011 & 2012 & 2012 \\
\hline $\begin{array}{l}\text { Team } \\
\text { assignment }\end{array}$ & $\begin{array}{l}\text { Adaptati } \\
\text { on }\end{array}$ & Adaptation & Mitigation & Adaptation & $\begin{array}{l}\text { Mitigatio } \\
\mathrm{n}\end{array}$ & Adaptation & Mitigation \\
\hline Duration & 6 weeks & 5 weeks & 5 weeks & 5 weeks & 5 weeks & 4 weeks & 4 weeks \\
\hline $\begin{array}{l}\text { Allocated } \\
\text { time per } \\
\text { week }\end{array}$ & $20 \%$ & $40 \%$ & $40 \%$ & $40 \%$ & $40 \%$ & $\begin{array}{l}\text { First } 3 \text { weeks: } \\
40 \%+\text { last } \\
\text { week: } 100 \%\end{array}$ & $\begin{array}{l}\text { First } 3 \text { weeks: } \\
40 \%+\text { last } \\
\text { week: } 100 \%\end{array}$ \\
\hline $\begin{array}{l}\text { Integration } \\
\text { with other } \\
\text { course } \\
\text { activities }\end{array}$ & $\begin{array}{l}\text { Integrate } \\
\mathrm{d} \text { in } \\
\text { weekly } \\
\text { E- } \\
\text { learning } \\
\text { modules } \\
\text { with } \\
\text { online } \\
\text { discussio } \\
\text { ns and } \\
\text { tests }\end{array}$ & $\begin{array}{l}\text { Integrated } \\
\text { in weekly } \\
\text { E-learning } \\
\text { modules } \\
\text { with online } \\
\text { discussions } \\
\text { and tests }\end{array}$ & $\begin{array}{l}\text { Integrated } \\
\text { in weekly } \\
\text { E-learning } \\
\text { modules } \\
\text { with online } \\
\text { discussions } \\
\text { and tests }\end{array}$ & $\begin{array}{l}\text { Integrated } \\
\text { in weekly } \\
\text { E-learning } \\
\text { modules } \\
\text { with online } \\
\text { discussions } \\
\text { and tests }\end{array}$ & $\begin{array}{l}\text { Integrate } \\
\mathrm{d} \text { in } \\
\text { weekly } \\
\text { E- } \\
\text { learning } \\
\text { modules } \\
\text { with } \\
\text { online } \\
\text { discussio } \\
\text { ns and } \\
\text { tests }\end{array}$ & $\begin{array}{l}\text { Running } \\
\text { parallel with } \\
\text { three weekly E- } \\
\text { learning } \\
\text { modules with } \\
\text { online } \\
\text { discussions and } \\
\text { tests + one } \\
\text { weak to } \\
\text { complete the } \\
\text { team } \\
\text { assignment }\end{array}$ & $\begin{array}{l}\text { Running } \\
\text { parallel with } \\
\text { four weekly E- } \\
\text { learning } \\
\text { modules with } \\
\text { online } \\
\text { discussions and } \\
\text { tests + one } \\
\text { weak to } \\
\text { complete the } \\
\text { team } \\
\text { assignment }\end{array}$ \\
\hline $\begin{array}{l}\text { Suggested } \\
\text { collaboration } \\
\text { platform } \\
\text { alternatives }\end{array}$ & None & $\begin{array}{l}\text { Messages, } \\
\text { other } \\
\text { chatrooms, } \\
\text { Skype }\end{array}$ & $\begin{array}{l}\text { Messages, } \\
\text { other } \\
\text { chatrooms, } \\
\text { Skype }\end{array}$ & $\begin{array}{l}\text { Messages, } \\
\text { other } \\
\text { chatrooms, } \\
\text { Skype }\end{array}$ & $\begin{array}{l}\text { Messages } \\
\text {, other } \\
\text { chatroom } \\
\text { s, Skype }\end{array}$ & $\begin{array}{l}\text { Messages, other } \\
\text { chatrooms, } \\
\text { Skype }\end{array}$ & $\begin{array}{l}\text { Messages, other } \\
\text { chatrooms, } \\
\text { Skype }\end{array}$ \\
\hline $\begin{array}{l}\text { Organisation } \\
\text { of group } \\
\text { work }\end{array}$ & $\begin{array}{l}\text { Every } \\
\text { week a } \\
\text { WIKI } \\
\text { "gardener } \\
\text { " is } \\
\text { assigned } \\
\text { to prune } \\
\text { the WIKI }\end{array}$ & $\begin{array}{l}\text { Every week } \\
\text { a teamwork } \\
\text { coordinator } \\
\text { is elected to } \\
\text { organize } \\
\text { the } \\
\text { teamwork } \\
\text { and secure } \\
\text { the } \\
\text { workflow }\end{array}$ & $\begin{array}{l}\text { Every week } \\
\text { a teamwork } \\
\text { coordinator } \\
\text { is elected to } \\
\text { organize } \\
\text { the } \\
\text { teamwork } \\
\text { and secure } \\
\text { the } \\
\text { workflow }\end{array}$ & $\begin{array}{l}\text { Every week } \\
\text { a teamwork } \\
\text { coordinator } \\
\text { is elected to } \\
\text { organize } \\
\text { the } \\
\text { teamwork } \\
\text { and secure } \\
\text { the } \\
\text { workflow }\end{array}$ & $\begin{array}{l}\text { Every } \\
\text { week a } \\
\text { teamwor } \\
\mathrm{k} \\
\text { coordinat } \\
\text { or is } \\
\text { elected to } \\
\text { organize } \\
\text { the } \\
\text { teamwor } \\
\mathrm{k} \text { and } \\
\text { secure } \\
\text { the } \\
\text { workflow }\end{array}$ & $\begin{array}{l}\text { Every week a } \\
\text { teamwork } \\
\text { coordinator is } \\
\text { elected to } \\
\text { organize the } \\
\text { teamwork and } \\
\text { secure the } \\
\text { workflow }\end{array}$ & $\begin{array}{l}\text { Every week a } \\
\text { teamwork } \\
\text { coordinator is } \\
\text { elected to } \\
\text { organize the } \\
\text { teamwork and } \\
\text { secure the } \\
\text { workflow }\end{array}$ \\
\hline $\begin{array}{l}\text { Proof of } \\
\text { completion }\end{array}$ & $\begin{array}{l}\text { Added } \\
\text { content } \\
\text { to the } \\
\text { WIKI }\end{array}$ & $\begin{array}{l}\text { Name } \\
\text { included on } \\
\text { final report }\end{array}$ & $\begin{array}{l}\text { Name } \\
\text { included on } \\
\text { final report }\end{array}$ & $\begin{array}{l}\text { Peer } \\
\text { assessment } \\
\text { had to } \\
\text { indicate } \\
\text { that the } \\
\text { student had } \\
\text { satisfactoril } \\
\text { y } \\
\text { contributed }\end{array}$ & $\begin{array}{l}\text { Peer } \\
\text { assessme } \\
\text { nt had to } \\
\text { indicate } \\
\text { that the } \\
\text { student } \\
\text { had } \\
\text { satisfacto } \\
\text { rily } \\
\text { contribut } \\
\text { ed }\end{array}$ & $\begin{array}{l}\text { Peer assessment } \\
\text { had to indicate } \\
\text { that the student } \\
\text { had } \\
\text { satisfactorily } \\
\text { contributed }\end{array}$ & $\begin{array}{l}\text { Peer assessment } \\
\text { had to indicate } \\
\text { that the student } \\
\text { had } \\
\text { satisfactorily } \\
\text { contributed }\end{array}$ \\
\hline $\begin{array}{l}\text { Assessment } \\
\text { weight }\end{array}$ & $0,00 \%$ & $5,88 \%$ & $5,88 \%$ & $5,88 \%$ & $5,88 \%$ & $12,50 \%$ & $12,50 \%$ \\
\hline $\begin{array}{l}\text { Exam } \\
\text { requirement } \\
\text { s }\end{array}$ & $\begin{array}{l}60 \% \text { of } \\
\text { course } \\
\text { tasks }\end{array}$ & $\begin{array}{l}\text { Peer } \\
\text { assessment } \\
\text { had to } \\
\text { indicate } \\
\text { that each } \\
\text { contributor } \\
\text { had a } \\
\text { satisfactory } \\
\text { contributio } \\
\text { n level }\end{array}$ & $\begin{array}{l}\text { Peer } \\
\text { assessment } \\
\text { had to } \\
\text { indicate } \\
\text { that each } \\
\text { contributor } \\
\text { had a } \\
\text { satisfactory } \\
\text { contributio } \\
\mathrm{n} \text { level }\end{array}$ & $\begin{array}{l}\text { Peer } \\
\text { assessment } \\
\text { had to } \\
\text { indicate } \\
\text { that each } \\
\text { contributor } \\
\text { had a } \\
\text { satisfactory } \\
\text { contributio } \\
\text { n level }\end{array}$ & $\begin{array}{l}\text { Peer } \\
\text { assessme } \\
\text { nt had to } \\
\text { indicate } \\
\text { that each } \\
\text { contribut } \\
\text { or had a } \\
\text { satisfacto } \\
\text { ry } \\
\text { contributi } \\
\text { on level }\end{array}$ & None & None \\
\hline
\end{tabular}




\begin{tabular}{|c|c|c|c|c|c|c|c|}
\hline Exam & $\begin{array}{l}100 \% \\
\text { final } 24 \\
\text { hour } \\
\text { written } \\
\text { exam } \\
\text { (estimate } \\
\text { d } \\
\text { workload } \\
8 \text { hours) }\end{array}$ & $\begin{array}{l}50 \% \\
\text { completion } \\
\text { of course } \\
\text { tasks and } \\
50 \% \text { final } \\
24 \text { hour } \\
\text { written } \\
\text { exam } \\
\text { (estimated } \\
\text { workload } 8 \\
\text { hours) }\end{array}$ & $\begin{array}{l}50 \% \\
\text { completion } \\
\text { of course } \\
\text { tasks and } \\
50 \% \text { final } \\
24 \text { hour } \\
\text { written } \\
\text { exam } \\
\text { (estimated } \\
\text { workload } 8 \\
\text { hours) }\end{array}$ & $\begin{array}{l}50 \% \\
\text { completion } \\
\text { of course } \\
\text { tasks and } \\
50 \% \text { final } \\
24 \text { hour } \\
\text { written } \\
\text { exam } \\
\text { (estimated } \\
\text { workload } 8 \\
\text { hours) }\end{array}$ & $\begin{array}{l}50 \% \\
\text { completi } \\
\text { on of } \\
\text { course } \\
\text { tasks and } \\
50 \% \text { final } \\
24 \text { hour } \\
\text { written } \\
\text { exam } \\
\text { (estimate } \\
\text { d } \\
\text { workload } \\
8 \text { hours) }\end{array}$ & $\begin{array}{l}50 \% \text { online } \\
\text { discussions, } \\
25 \% \text { team } \\
\text { assignments and } \\
25 \% \text { individual } \\
\text { assignments }\end{array}$ & $\begin{array}{l}50 \% \text { online } \\
\text { discussions, } \\
25 \% \text { team } \\
\text { assignments and } \\
25 \% \text { individual } \\
\text { assignments }\end{array}$ \\
\hline $\begin{array}{l}\text { Primary } \\
\text { driving force } \\
\text { for changes }\end{array}$ & $\begin{array}{l}\text { WIKI } \\
\text { format } \\
\text { did not } \\
\text { work } \\
\text { well. }\end{array}$ & $\begin{array}{l}\text { Was made } \\
\text { mandatory } \\
\text { from } 2010 \\
\text { onwards to } \\
\text { prevent } \\
\text { free-rider } \\
\text { problem. }\end{array}$ & & & & $\begin{array}{l}\text { TAs were } \\
\text { pulled out of the } \\
\text { e-lessons and } \\
\text { became their } \\
\text { own separate } \\
\text { thing with one } \\
\text { entire week to } \\
\text { compete it prior } \\
\text { to submission } \\
\text { deadline. }\end{array}$ & \\
\hline
\end{tabular}

